\title{
Internucleosomal DNA Fragmentation during Phorbol Ester-induced Monocytic Differentiation and $G_{0} / G_{1}$ Arrest
}

\author{
Hisato Gunji, Ralf Hass, and Donald Kufe \\ Laboratory of Clinical Pharmacology, Dana-Farber Cancer Institute, Harvard Medical School, Boston, Massachusetts 02115
}

\begin{abstract}
The treatment of human myeloid leukemia cell lines with phorbol esters, such as 12-O-tetradecanoylphorbol-13-acetate (TPA), is associated with loss of proliferative capacity and induction of monocytic differentiation. The present results demonstrate that treatment of asynchronous human U-937 leukemia cells with $10 \mathrm{nM}$ TPA is also associated with oligonucleosomal DNA cleavage. This pattern of DNA fragmentation, which is observed in programmed cell death, was detectable in populations of TPA-treated cells that had entered a nonproliferative $G_{0} / G_{1}$ phase. Similar findings were obtained after TPA treatment of a synchronous population of $G_{1}$ cells. These cells progressed through $S$ and $G_{2} / M$ phases before undergoing internucleosomal DNA cleavage during $\mathbf{G}_{0} / \mathbf{G}_{1}$ arrest. These $\mathbf{G}_{0} / \mathbf{G}_{1}$ cells displayed characteristics of monocytic differentiation, including down-regulation of $c-m y c$ expression and induction of c-fms transcripts. DNA fragmentation was also studied in cells treated with $5 \mathrm{nM}$ TPA for $48 \mathrm{~h}$ and then monitored in drugfree long-term culture. Endonucleolytic cleavage was similarly observed in the differentiated $G_{0} / G_{1}$ population. However, longer periods of culture were associated with a decrease in DNA fragmentation to undetectable levels. This effect was followed by retrodifferentiation and reentry of cells into cycle. Taken together, these findings demonstrate that internucleosomal DNA fragmentation occurs during induction of monocytic differentiation, and that both of these events are detectable in $G_{0} / G_{1}$ cells. (J. Clin. Invest. 1992. 89:954-960.) Key words: cell cycle $\bullet$ DNA cleavage $\bullet$ retrodifferentiation $\bullet$ TPA
\end{abstract}

\section{Introduction}

Programmed cell death, or apoptosis, is a regulated process during which eukaryotic cells die in response to specific stimuli (1). This process provides a mechanism for deletion of specific cell populations in the developing embryo (2). Apoptosis is also associated with death of lymphocytes treated with glucocorticoids (3) and elimination of autoreactive T-cell clones in the thymus $(4,5)$. The death of these cells is preceded by chromatin

Address reprint request to $\mathrm{H}$. Gunji, Laboratory of Clinical Pharmacology, Dana-Farber Cancer Institute, Harvard Medical School, Boston, MA 02181.

Received for publication 24 June 1991 and in revised form 1 November 1991.

1. Abbreviations used in this paper: MEL, murine erythroleukemia; TPA, 12-O-tetradecanoylphorbol-13-acetate.

J. Clin. Invest.

(c) The American Society for Clinical Investigation, Inc.

0021-9738/92/03/0954/07 \$2.00

Volume 89, March 1992, 954-960 condensation and cleavage at internucleosomal sites $(3,6)$. Thus, one characteristic of apoptosis is internucleosomal DNA fragmentation. The mechanisms responsible for this endonucleolytic DNA cleavage remain unclear. Nonetheless, similar patterns of DNA fragmentation have been observed in lymphocytes deprived of IL-2 (7) and in myeloid cells deprived of colony-stimulating factors $(8,9)$. These findings have indicated that certain growth factors may promote survival by suppressing apoptosis (7-9).

Human myeloid leukemia cell lines, such as HL-60 and U-937, proliferate autonomously $(10,11)$. However, these cells have retained the capacity to respond to inducers of differentiation with cessation of growth and appearance of a more mature phenotype (12). For example, treatment of U-937 or HL-60 cells with $12-O$-tetradecanoylphorbol-13-acetate (TPA) ${ }^{1}$ is associated with loss of proliferative capacity, adherence, and increased expression of monocyte surface markers $(13,14)$. TPAinduced monocytic differentiation of these cell lines is also associated with down-regulation of $c-m y c$ expression and induction of c-fos, c-jun, and c-fms transcripts $(15,16)$. The $c-m y c, c-f o s$, and c-jun immediate early response genes code for nuclear proteins, whereas the c-fms gene codes for the macrophage colony-stimulating factor receptor, a marker of differentiation along the monocytic lineage (17). Although c-fms mRNA levels are increased during TPA-induced growth arrest, the relationship, if any, between expression of this gene and cell cycle events is unknown.

Previous studies have demonstrated that differentiation of eukaryotic cells is associated with DNA strand breaks (18-22). However, the mechanisms responsible for this fragmentation of DNA have remained unclear. The present studies were performed to determine whether induction of monocytic differentiation is associated with DNA cleavage at internucleosomal sites. The results demonstrate that DNA of TPA-induced U-937 cells is cleaved into multiples of nucleosome-sized fragments. This pattern of DNA cleavage was found in cells that were arrested in $G_{0} / G_{1}$ and expressed the differentiated phenotype. These findings suggest that induction of differentiation includes at least one characteristic of programmed cell death.

\section{Methods}

Cell culture. U-937 and HL-60 myeloid leukemia cells (American Type Culture Collection, Rockville, MD) were grown in RPMI 1640 medium supplemented with $10 \%$ (U-937) or $15 \%$ (HL-60) heat-inactivated fetal bovine serum, $100 \mathrm{U} / \mathrm{ml}$ penicillin, and $100 \mu \mathrm{g} / \mathrm{ml}$ streptomycin. The cells were treated with 5 and $10 \mathrm{nM}$ TPA (Sigma Chemical Co., St. Louis, MO) or 1.5\% DMSO (Sigma Chemical Co.).

Centrifugal elutriation. Cells in exponential growth phase or after treatment with TPA were subjected to centrifugal elutriation using the JE-5.0 elutriation system (Beckman Instruments, Inc., Palo Alto, CA). Approximately $2 \times 10^{8}$ cells were applied to the standard chamber $\left(1,600 \mathrm{rpm}\right.$ at $\left.27^{\circ} \mathrm{C}\right)$ using a digital flow controller (Cole-Parmer Instrument Co., Chicago, IL). The calibrated pump speed was increased 


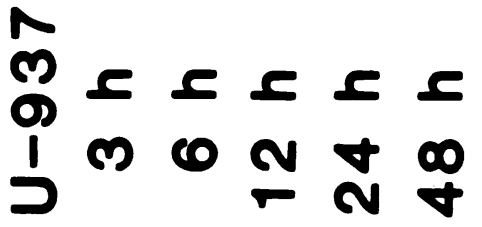

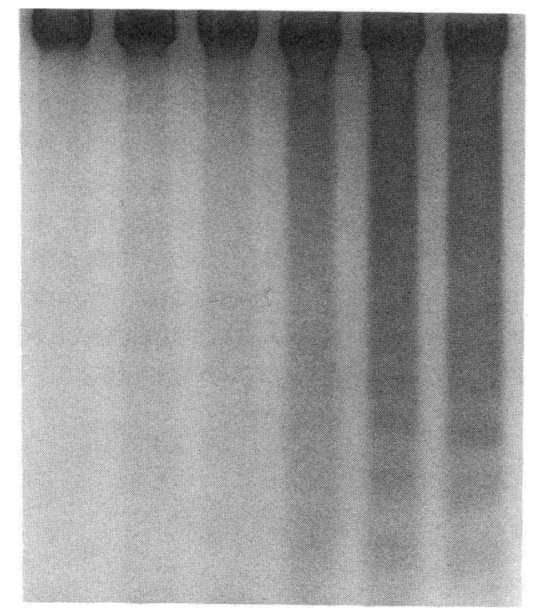

Figure 1. Effects of TPA on DNA fragmentation in asynchronous cells. U-937 cells were treated with $10 \mathrm{nM}$ TPA for the indicated times. The cells were washed and then monitored for DNA fragmentation in $2 \%$ agarose gels.

from 10 to $30 \mathrm{ml} / \mathrm{min}$. Enriched cell populations from different phases of the cell cycle were elutriated in 100-ml aliquots of RPMI 1640 medium containing $1 \%$ fetal bovine serum. Aliquots $(1 \mathrm{ml})$ were fixed by adding $2 \mathrm{ml}$ of ice-cold methanol for $60 \mathrm{~min}$ on ice. After centrifugation, the supernatant was removed and the cell pellet incubated with $500 \mu \mathrm{l}$ of RNase $(200 \mathrm{U} / \mathrm{ml})$ and $500 \mu$ l of propidium iodide buffer in the dark at room temperature for $30 \mathrm{~min}$ (23). The stained cells were analyzed for DNA content on a FACScan (Becton, Dickinson \& Co., Mountain View, CA) using CellFIT cell cycle analysis software.

Analysis of DNA fragmentation. $1 \times 10^{6}$ cells were harvested, washed, and incubated in $20 \mu \mathrm{l}$ of $50 \mathrm{mM}$ Tris- $\mathrm{HCl}(\mathrm{pH} 8.0), 10 \mathrm{mM}$ EDTA, $0.5 \%$ SDS, and $0.5 \mu \mathrm{g} / \mathrm{ml}$ proteinase K (Sigma Chemical Co.)
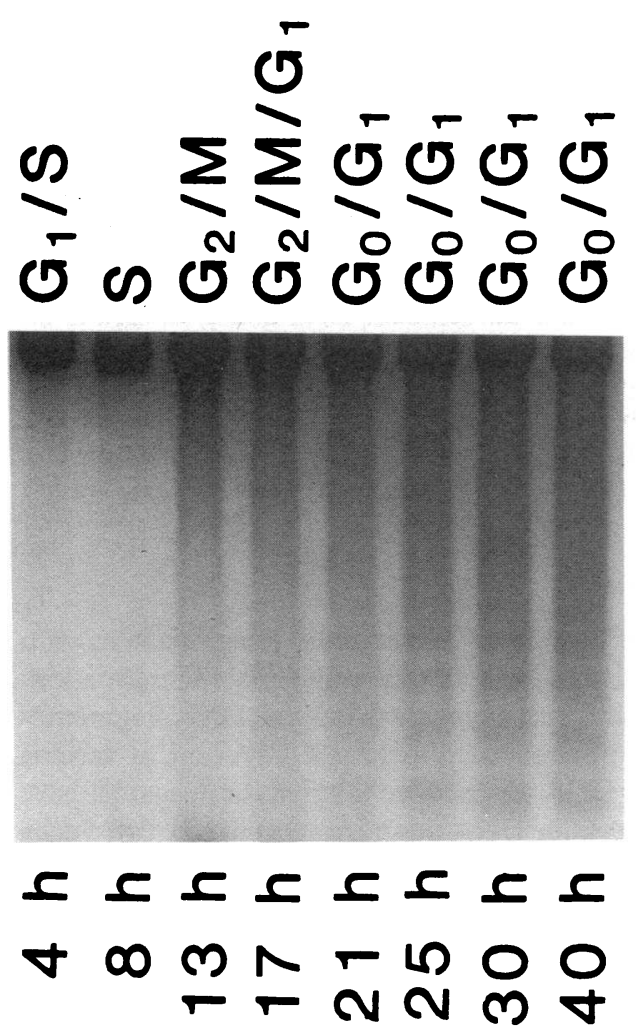

Figure 3. DNA fragmentation after treatment of $G_{1}$ cells with TPA. U-937 cells in exponential growth phase were separated by elutriation. The $\mathrm{G}_{1}$ phase $\left(79 \% \mathrm{G}_{1}, 18 \% \mathrm{~S}, 3 \% \mathrm{G}_{2} / \mathrm{M}\right)$ cells were isolated and treated with $10 \mathrm{nM}$ TPA. TPA-treated cells were harvested at the indicated times for analysis of cell cycle distribution and DNA fragmentation. $\mathrm{G}_{1} / \mathrm{S}: 54 \% \mathrm{G}_{1}, 34 \% \mathrm{~S}, 12 \% \mathrm{G}_{2} / \mathrm{M}$. S: $35 \% \mathrm{G}_{1}, 39 \% \mathrm{~S}, \mathbf{2 6 \%}$ $\mathrm{G}_{2} / \mathrm{M} . \mathrm{G}_{2} / \mathrm{M}: 35 \% \mathrm{G}_{1}, 30 \% \mathrm{~S}, 35 \% \mathrm{G}_{2} \mathrm{M} . \mathrm{G}_{2} / \mathrm{M} / \mathrm{G}_{1}: 61 \% \mathrm{G}_{1}, 7 \% \mathrm{~S}$, $32 \% \mathrm{G}_{2} / \mathrm{M} . \mathrm{G}_{0} / \mathrm{G}_{1} 21 \mathrm{~h}: 78 \% \mathrm{G}_{1}, 8 \% \mathrm{~S}, 14 \% \mathrm{G}_{2} / \mathrm{M} \mathrm{G}_{0} / \mathrm{G}_{1} 25 \mathrm{~h}: 85 \%$ $\mathrm{G}_{1}, 6 \% \mathrm{~S}, 9 \% \mathrm{G}_{2} / \mathrm{M} . \mathrm{G}_{0} / \mathrm{G}_{1} 30 \mathrm{~h}: 87 \% \mathrm{G}_{1}, 4 \% \mathrm{~S}, 9 \% \mathrm{G}_{2} / \mathrm{M}$.
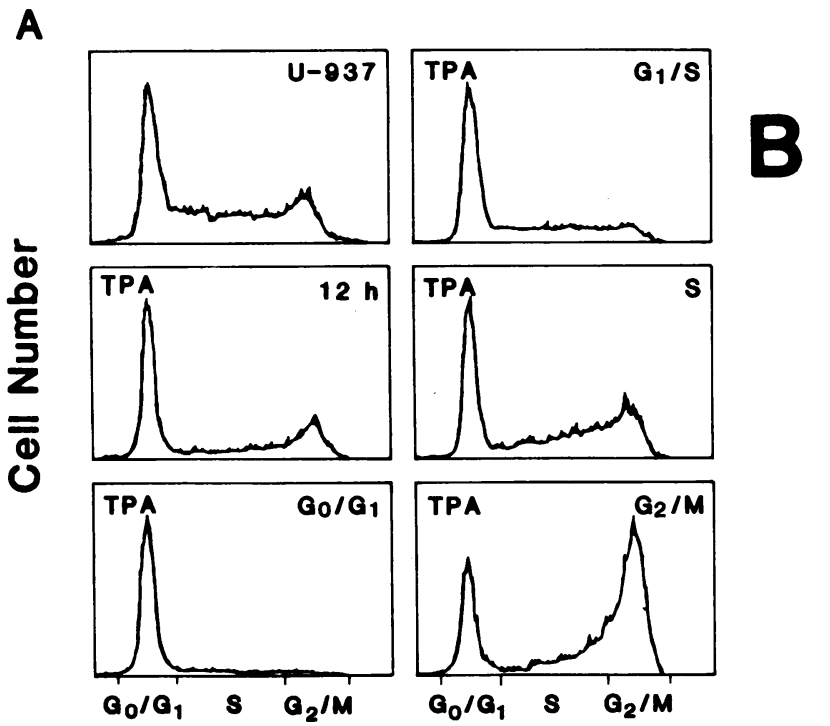

Fluorescence Intensity

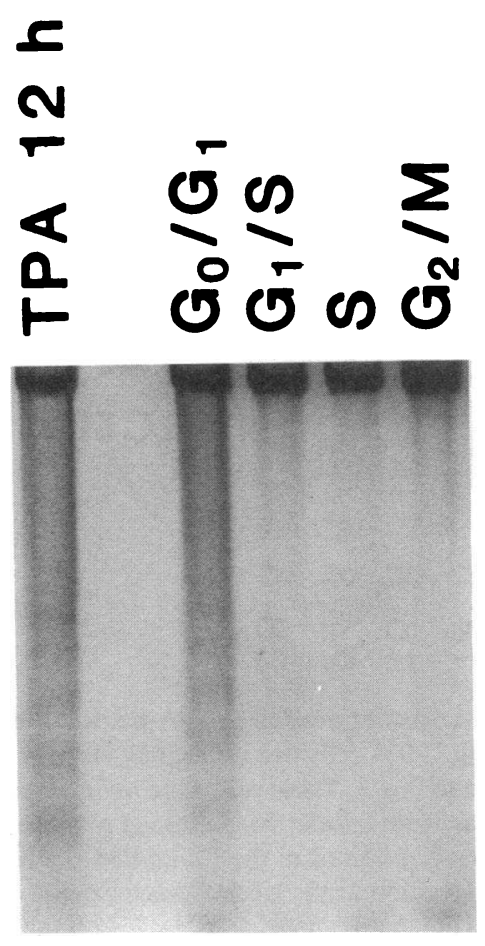

Figure 2. Cell cycle distribution and DNA fragmentation in TPA-treated cells. U-937 cells were treated with $10 \mathrm{nM}$ TPA for $12 \mathrm{~h}$ and then separated by centrifugal elutriation. $(A)$ Control U-937 cells (top left panel) and TPA-treated cells (middle left panel) were analyzed by flow cytometry. The elutriated fractions obtained from the TPA-treated cells were also analyzed by flow cytometry for cell cycle distribution. $\mathrm{G}_{0} / \mathrm{G}_{1}: \mathbf{8 0 \%}$ $\mathrm{G}_{0} / \mathrm{G}_{1}, 19 \% \mathrm{~S}, 1 \% \mathrm{G}_{2} / \mathrm{M}$ $\mathrm{G}_{1} / \mathrm{S}: 54 \% \mathrm{G}_{1}, 35 \% \mathrm{~S}$, $11 \% \mathrm{G}_{2} / \mathrm{M}$. S: $37 \% \mathrm{G}_{1}$, $40 \% \mathrm{~S}, 23 \% \mathrm{G}_{2} / \mathrm{M} . \mathrm{G}_{2} / \mathrm{M}$ : $23 \% \mathrm{G}_{1}, 20 \% \mathrm{~S}, 57 \% \mathrm{G}_{2} /$ M. (B) The same elutriated fractions were monitored for DNA fragmentation in $2 \%$ agarose gels. 
for $1 \mathrm{~h}$ at $50^{\circ} \mathrm{C} .10 \mu \mathrm{l}$ of $0.5 \mu \mathrm{g} / \mathrm{ml}$ RNase A was then added and the incubation continued for an additional $1 \mathrm{~h}$. The digested samples were incubated with $10 \mu \mathrm{l}$ of $10 \mathrm{mM}$ EDTA ( $\mathrm{pH} 8.0$ ) containing $2 \%$ (wt/vol) low-melting-point agarose, $0.25 \%$ bromophenol blue, and $40 \%$ sucrose at $70^{\circ} \mathrm{C}$. The DNA was separated in $2 \%$ agarose gels and visualized by ultraviolet (UV) illumination after ethidium bromide staining.

Isolation and analysis of RNA. Total cellular RNA was purified as described (15), analyzed by electrophoresis through $1 \%$ agarose-formaldehyde gels, transferred to nitrocellulose filters and hybridized to the following ${ }^{32} \mathrm{P}$-labeled DNA probes: $(a)$ the $1.6-\mathrm{kb} \mathrm{ClaI} / \mathrm{EcoRI}$ fragment of the human c-myc 3' exon purified from the pMC41-3 RC plasmid (24); (b) the 4.0-kb EcoRI fragment of the human c-fms gene purified from the pc-fms 102 plasmid (25); and (c) the 2.0-kb PstI fragment of the chicken $\beta$-actin gene purified from the pAI plasmid (26).

\section{Results}

The treatment of human U-937 myeloid leukemia cells with TPA is associated with induction of monocytic differentiation. To determine whether this agent also induces DNA fragmentation, U-937 cells were exposed to $10 \mathrm{nM}$ TPA and, at various intervals, nuclear DNA was isolated for analysis in agarose gels. There was no detectable DNA fragmentation in untreated cells

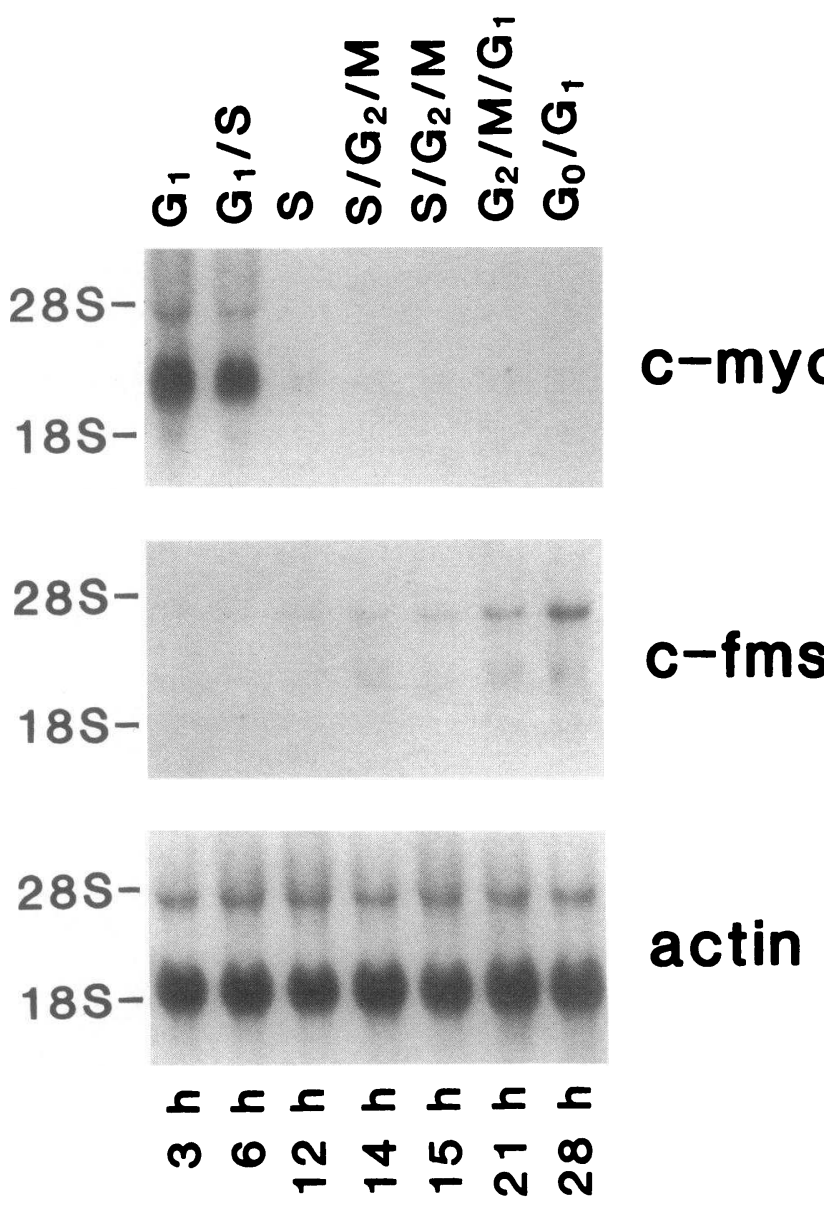

Figure 4. Analysis of c-myc and c-fms expression in TPA-treated cells. The $G_{1}$ fraction of proliferating U-937 cells was isolated by elutriation, as described in the legend to Fig. 3. These cells were maintained in the presence of $10 \mathrm{nM}$ TPA. Total cellular RNA $(20 \mu \mathrm{g})$ was isolated at the indicated times and hybridized to the ${ }^{32} \mathrm{P}$-labeled c-myc and c-fms DNA probes. Hybridization to the labeled $\beta$-actin probe demonstrated equal loading of the lanes.
(Fig. 1). Moreover, there was no evidence of fragmentation after exposure to TPA for 3 or $6 \mathrm{~h}$ (Fig. 1). In contrast, DNA fragments at multiples of $\sim 200 \mathrm{bp}$ were present at low but detectable levels in cells treated for $12 \mathrm{~h}$; this pattern was more apparent with longer exposures (Fig. 1). This pattern of fragmentation is in concert with internucleosomal DNA cleavage.

To determine whether DNA fragmentation occurs in specific phases of the cell cycle, U-937 cells were treated with 10 $\mathrm{nM}$ TPA for $12 \mathrm{~h}$ and then subjected to centrifugal elutriation. Cell cycle distribution of the elutriated cells was determined by flow cytometry. Although cells were detectable in $S$ and $G_{2} / \mathbf{M}$ phases, other cells had exited the cycle and entered $G_{0} / G_{1}$ (Fig. $2 A$ ). This $\mathrm{G}_{0} / \mathrm{G}_{1}$ population failed to reenter $\mathrm{S}$ phase (data not shown). Moreover, cells remaining in cycle subsequently underwent exit to $G_{0} / G_{1}$ (data not shown). DNA from the elutriated cell fractions was also analyzed in agarose gels. In con-

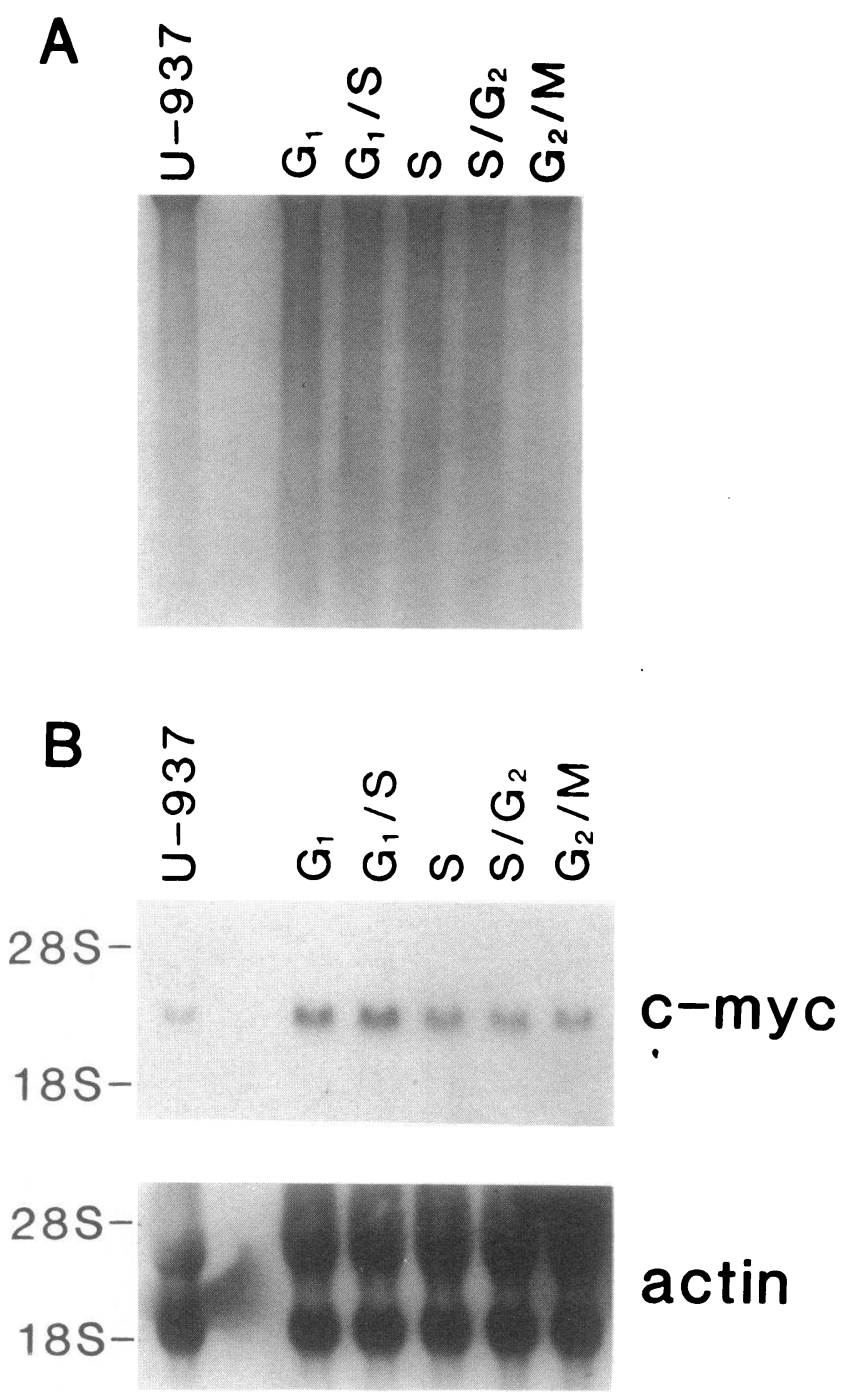

Figure 5. Analysis of uninduced U-937 cells for DNA fragmentation and c-myc expression. U-937 cells in exponential growth phase were separated by elutriation. $(A)$ Aliquots were analyzed for cell cycle distribution by flow cytometry and for DNA fragmentation in agarose gels. $(B)$ Total cellular RNA $(20 \mu \mathrm{g})$ was also isolated from these cell populations and hybridized to the ${ }^{32} \mathrm{P}$-labeled c-myc probe. Hybridization to the actin probe was used to demonstrate equal loading of the lanes. 


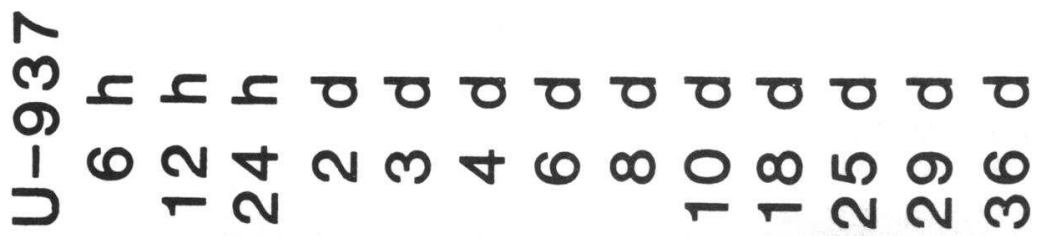

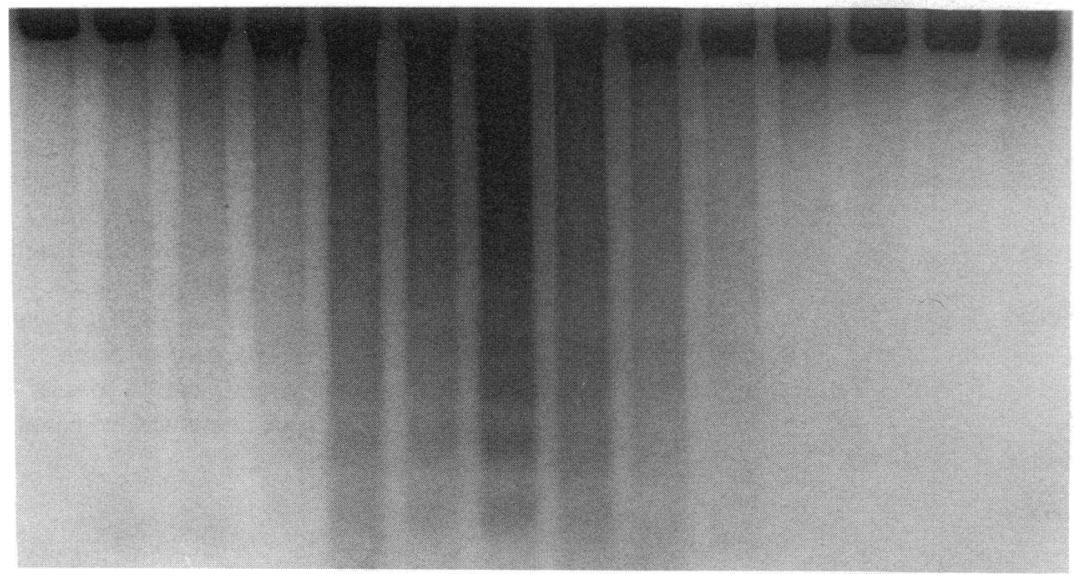

Figure 6. DNA fragmentation during long-term culture after TPA induction. U-937 cells were treated with $5 \mathrm{nM}$ TPA for $48 \mathrm{~h}$ and then maintained in the absence of this agent. Cells were harvested at the indicated times and analyzed for DNA fragmentation. trast to the unfractionated population, there was no evidence for DNA fragmentation in $\mathrm{S}$ or $\mathrm{G}_{2} / \mathrm{M}$ phase cells (Fig. $2 \mathrm{~B}$ ). However, internucleosomal DNA cleavage was detectable in the $G_{0} / G_{1}$ cell fraction (Fig. $2 B$ ). These findings indicated that DNA fragmentation occurs predominantly, if not exclusively, in cells that exit the cycle to $G_{0} / G_{1}$.

Other studies were performed on $\mathrm{G}_{1}$ cells isolated by elutriation of a population in exponential growth phase. The $G_{1}$ cell fraction was treated with TPA and, at various intervals, assayed for cell cycle distribution and DNA fragmentation. These TPA-treated cells progressed through $S$ and $G_{2} / M$ phases before arrest in $G_{0} / G_{1}$ (Fig. 3). There was no evidence for DNA cleavage in cells that remained in cycle (Fig. 3). However, oligonucleosomal DNA fragmentation was detectable in cells that had undergone exit to $G_{0} / G_{1}$ (Fig. 3). Previous studies have demonstrated that treatment of U-937 cells with TPA is associated with down-regulation of $c-m y c$ transcripts and induction

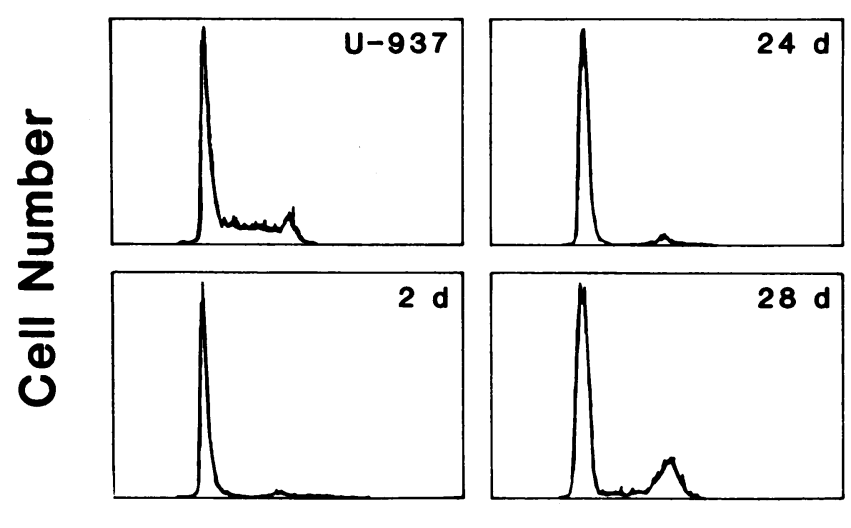

\section{Fluorescence Intensity}

Figure 7. Cell cycle distribution during TPA induction and retrodifferentiation. U-937 cells were treated as described in the legend to Fig. 5. Cells were harvested at the indicated times for analysis of cell cycle distribution by flow cytometry. of c-fms gene expression (15). The relationship between these events and internucleosomal DNA fragmentation was studied by performing Northern analyses on RNA from $\mathrm{G}_{1}$ cells maintained in the presence and absence of TPA. Although c-myc expression was detectable in the $G_{1} / S$ phase fraction of TPAinduced cells, induction of c-fms mRNA was found predominantly in the subsequent $G_{0} / G_{1}$ fraction (Fig. 4). In contrast, there was no detectable internucleosomal DNA fragmentation in uninduced U-937 cells subjected to elutriation (Fig. $5 \mathrm{~A}$ ). Moreover, although c-myc mRNA levels were highest in $G_{1} / S$ cells and decreased with cell cycle progression (Fig. $5 \mathrm{~B}$ ), there was no detectable expression of the c-fms gene in the absence of TPA treatment (data not shown). These results indicated that the exit of TPA-treated cells to $G_{0} / G_{1}$ is associated with induction of both the monocytic phenotype and internucleosomal DNA cleavage.

The relationship between differentiated $G_{0} / G_{1}$ cells and DNA fragmentation was further studied during long-term culture of TPA-treated U-937 cells. We have previously demonstrated that differentiated U-937 cells grown in the absence of TPA for $>28 \mathrm{~d}$ is associated with retrodifferentiation and reentry of growth-arrested cells into the cycle (27). To determine whether internucleosomal cleavage occurs during this process, U-937 cells were treated with $5 \mathrm{nM}$ TPA for $48 \mathrm{~h}$ and then maintained in TPA-free medium for up to $36 \mathrm{~d}$. Using these experimental conditions, DNA fragmentation was initially detectable at low levels by 2-3 d (Fig. 6). Maximal DNA cleavage at internucleosomal sites was found at $4 \mathrm{~d}$, whereas longer periods of incubation were associated with a progressive decrease in fragmentation to undetectable levels by $10 \mathrm{~d}$ (Fig. 6). These results indicated that the induction of DNA fragmentation is transient during long-term culture.

Flow cytometry to determine cell cycle distribution was performed on TPA-induced cells monitored in the absence of this agent. Before induction with TPA, 50, 40, and $10 \%$ of the cells were present in $G_{1}, S$, and $G_{2} / M$ phases, respectively (Fig. 7). An accumulation of $G_{0} / G_{1}$ cells $(>90 \%)$ was detectable by 2 d (Fig. 7). Although similar findings were obtained at day 24, 

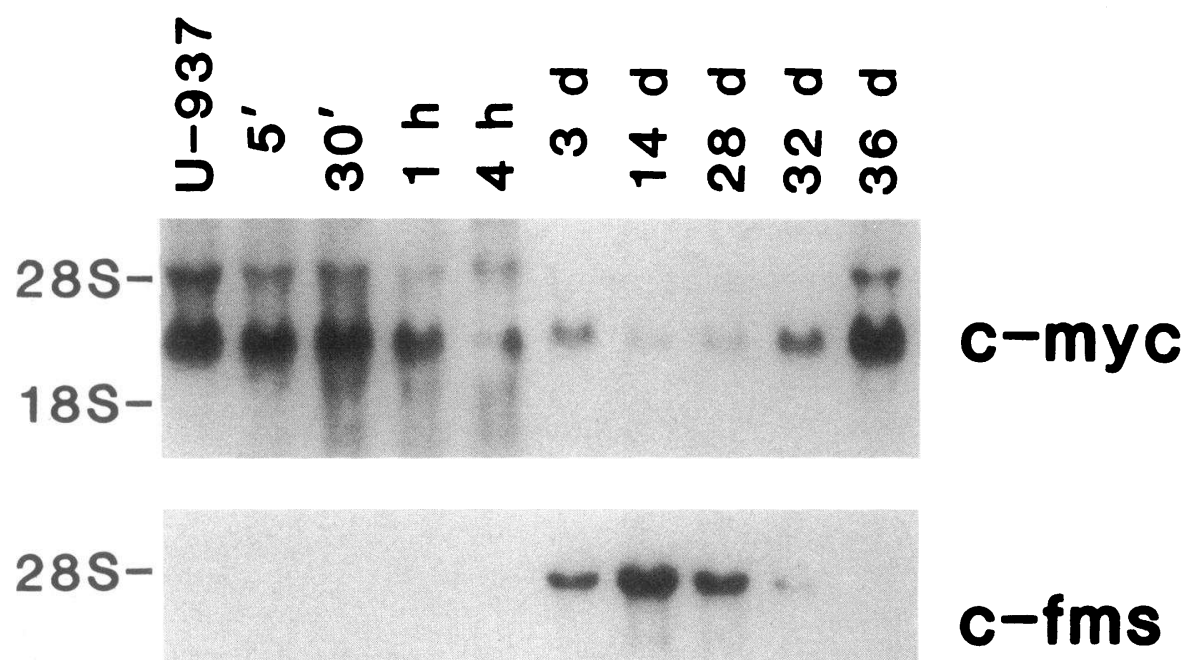

Figure 8. Expression of the c-myc and c-fms genes during retrodifferentiation. U-937 cells were treated as described in the legend to Fig. 5. Cells were harvested at the indicated times. Total cellular RNA $(20 \mu \mathrm{g})$ was hybridized to the ${ }^{32} \mathrm{P}$-labeled $\mathrm{c}-\mathrm{myc}$ and c-fms DNA probes. Hybridization to a labeled 28-S DNA probe demonstrated equal loading of the lanes.

these cells were redistributed through $S$ and $G_{2} / M$ phase by day 28 (Fig. 7). This pattern of reentry into the cell cycle is in concert with the previous demonstration that after day 28 the TPA-induced cells detach and reinitiate proliferation. These changes in cell cycle distribution were also associated with down-regulation of c-myc transcripts and induction of c-fms expression during periods of $G_{0} / G_{1}$ arrest (Fig. 8). In contrast, reentry of the cells into cycle was preceded by induction of c-myc expression and down-regulation of the c-fms gene (Fig. 8). Taken together, these results indicated that internucleosomal DNA fragmentation occurs in association with $G_{0} / G_{1}$ arrest and induction of monocytic differentiation.

To determine whether endonucleolytic DNA cleavage is limited to TPA-treated U-937 cells, we performed similar studies with the HL-60 myeloid leukemia cell line. There was no detectable DNA fragmentation in untreated HL-60 cells, while treatment with TPA for $24 \mathrm{~h}$ was associated with induction of adherence and internucleosomal DNA fragmentation (Fig. 9 A). Recent work has demonstrated that DMSO also induces monocytic differentiation of U-937 cells (28). Treatment of U-937 cells with this agent was similarly associated with internucleosomal fragmentation (Fig. $9 \mathrm{~B}$ ). This effect was predominant at 72 and $96 \mathrm{~h}$ when the cells entered $G_{0} / G_{1}$ and exhibited loss of proliferative capacity (Fig. $9 \mathrm{~B}$ ). These findings suggested that induction of differentiation with distinct classes of agents is associated with internucleosomal DNA fragmentation.

\section{Discussion}

Previous work has demonstrated that deprivation of growth factors results in programmed cell death in factor-dependent hematopoietic cells (7-9). An early event in this process is the fragmentation of chromatin at internucleosomal sites (7-9). These findings have suggested that apoptosis is suppressed by growth factor stimulation and that programmed cell death may represent a mechanism for selective elimination of cells no longer under autocrine or paracrine control. Indeed, the absence of apoptosis or decreases in the ability of cells to undergo this process may characterize the growth of leukemic popula- tions. However, little is known about the events responsible for the activation of programmed cell death. Furthermore, it is not known whether endonucleoytic DNA cleavage, one characteristic of programmed cell death, is even linked to specific events during cell cycle progression.

The present findings demonstrate that internucleosomal DNA fragmentation occurs during TPA-induced monocytic differentiation of U-937 cells. These findings are not limited to U-937 cells since similar results have been obtained during induction of the HL-60 and THP-1 myeloid leukemia cell lines

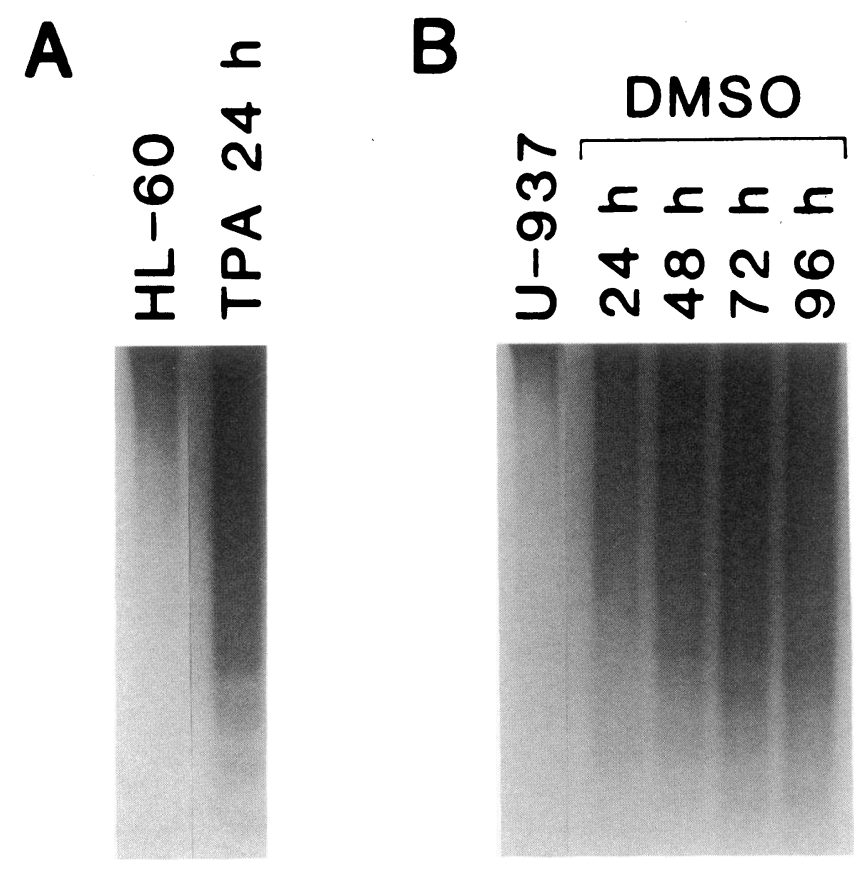

Figure 9. Analysis of internucleosomal DNA fragmentation in TPAtreated HL-60 cells and DMSO-treated U-937 cells. $(A)$ HL-60 cells were treated with $10 \mathrm{nM}$ TPA for $24 \mathrm{~h}$. (B) U-937 cells were treated with $1.5 \%$ DMSO for the indicated times. The cells were washed and monitored for DNA fragmentation. 
(data not shown). To our knowledge, there are no prior reports of DNA cleavage during monocytic differentiation. Other studies have demonstrated that induction of murine erythroleukemia (MEL) cell differentiation with various agents is associated with accumulation of DNA strand breaks $(18,19)$. Moreover, DNA cleavage during MEL differentiation is related to induction of a Ca ${ }^{2+}, \mathrm{Mg}^{2+}$-dependent endonuclease activity (22). This activity is similar to that described during internucleosomal DNA cleavage of glucocorticoid-treated thymocytes (29). However, there is no report as yet that oligonucleosomal DNA fragmentation is induced during MEL differentiation. In the present work, the kinetics of DNA cleavage were dependent on the concentration of TPA used to induce differentiation. Although the activation of endonucleolytic cleavage may have been related to the use of TPA rather than to induction of monocytic differentiation, similar patterns of DNA fragmentation were obtained with DMSO, another agent that differentiates U-937 cells along the monocytic lineage (28).

The present results further demonstrate that internucleosomal DNA cleavage is limited to cells that enter a nonproliferative $G_{0} / G_{1}$ phase. In this context, only TPA-induced cells in $\mathrm{G}_{0} / \mathrm{G}_{1}$, not cells in $S$ or $\mathrm{G}_{2} / \mathrm{M}$ phase, had detectable DNA fragmentation. Differentiation of myeloid leukemia cells is associated with loss of proliferation, although it has not been clear whether appearance of the differentiated phenotype is limited to arrest in a certain phase. Expression of the c- $f m s$ gene represents a specific marker of monocytic differentiation. The finding that c-fms transcripts were detectable only in cells that had entered $G_{0} / G_{1}$ suggested that this population was indeed differentiated along the monocytic lineage. Moreover, the finding by in situ hybridization that 99\% of TPA-induced cells express the c-fms gene (30) indicates that cells that exit the cycle express the mature monocytic phenotype. Taken together, these results would support the activation of endonucleolytic DNA cleavage in differentiated $G_{0} / G_{1}$ cells.

Further support for the induction of endonucleolytic activity during monocytic differentiation was obtained from the study of TPA-induced U-937 cells as they undergo retrodifferentiation. Long-term culture of U-937 cells in the absence of TPA is associated with reentry of a growth-arrested population into the cell cycle $(27,31,32)$. Similar findings have been obtained with other myeloid leukemia cell lines(27). Studies with $\left[{ }^{3} \mathrm{H}\right]$ TPA demonstrate that $\mathrm{U}-937$ cells retrodifferentiate when intracellular levels of this phorbol ester decline to $<1 \%$ of initial binding (31). This event is not related to the selection of TPA-resistant cells since reexposure to TPA is associated with reinduction of differentiation $(27,31,32)$. In contrast to lymphoid cells, which are known to reenter $S$ from a quiescent $G_{0} / G_{1}$ phase, this capability has not been described for myeloid cells.

The present results confirm that U-937 cells induced with TPA for $48 \mathrm{~h}$ subsequently enter a nonproliferative but reversible $G_{0} / G_{1}$ state. Moreover, the finding that this quiescent cell population was adherent and expressed the c-fms gene is in concert with induction of the monocytic phenotype. These cells also demonstrated internucleosomal DNA fragmentation, although this effect was transient and disappeared before retrodifferentiation. One possible but unlikely explanation for these findings is that cells can repair oligonucleosomal cleavage. Alternatively, a differentiated cell population with DNA fragmentation may have been eliminated from the culture, while the surviving cells retained the capacity to undergo retrodiffer- entiation and reenter a proliferative state. Indeed, 25-30\% of the cells detach and die during the same period in which we observed the decrease in internucleosomal DNA fragmentation (27). These findings suggest that the balance between differentiated cells committed to programmed cell death or retrodifferentiation could be relevant to expansion of normal or leukemic myeloid cell populations.

\section{Acknowledgments}

This investigation was supported by U. S. Public Health Service grants CA-42802 and CA-34183 awarded by the National Cancer Institute; a Fellowship from the Deutsche Forschungsgemeinschaft (R. Hass); and Burroughs Wellcome Clinical Pharmacology Scholar Award (D. Kufe).

\section{References}

1. Kerr, J. F. R., A. H. Wyllie, and A. R. Currie. 1972. Apoptosis: a basic biological phenomenon with wide-ranging implications in tissue kinetics. $B r$. $J$. Cancer. 26:239-257.

2. Hinchliffe, J. R. 1981. Cell death in embryogenesis. In: Cell Death in Biology and Pathology. I. D. Bowen and R. A. Lockshin, editors. Chapman and Hall Press, London/New York. 35-78.

3. Wyllie, A. H. 1980. Glucocorticoid-induced thymocyte apoptosis is associated with endogenous endonuclease activation. Nature (Lond.). 284:555-556.

4. Smith, C. A., G. T. Williams, R. Kingston, E. J. Jenkinson, and J. T. Owen. 1989. Antibodies to CD3/T-cell receptor complex induce death by apoptosis in immature T cells in thymic cultures. Nature (Lond.). 337:181-184.

5. Shi, Y., B. M. Sahai, and D. R. Green. 1989. Cyclosporin A inhibits activation-induced cell death in T-cell hybridomas and thymocytes. Nature (Lond.). 339:625-626.

6. Arends, M. J., R. G. Morris, and A. H. Wyllie. 1990. Apoptosis: the role of the endonuclease. Am. J. Pathol. 136:593-608.

7. Duke, R. C., and J. J. Cohen. 1986. IL-2 addiction: withdrawal of growth factor activates a suicide program in dependent T cells. Lymphokine Res. 5:289299.

8. Williams, G. T., C. A. Smith, E. Spooncer, T. M. Dexter, and D. R. Taylor. 1990. Haemopoietic colony stimulating factors promote cell survival by suppressing apoptosis. Nature (Lond.). 343:76-79.

9. Rodriguez-Tarduchy, G., M. Collins, and A. Lopez-Rivas. 1990. Regulation of apoptosis in interleukin-3-dependent hemopoietic cells by interleukin-3 and calcium ionophores. EMBO (Eur. Mol. Biol. Organ.) J. 9:2997-3002.

10. Collins, S. J. 1987. The HL-60 promyelocytic leukemia cell line: proliferation, differentiation, and cellular oncogene expression. Blood. 70:1233-1244.

11. Sundstrom, C., and K. Nilsson. 1976. Establishment and characterization of a human histiocytic lymphoma cell line (U-937). Int. J. Cancer. 17:565-577.

12. Koeffler, H. P. 1983. Induction of differentiation of human acute myelogenous leukemia cells: therapeutic implications. Blood. 62:709-721.

13. Rovera, G., T. G. O'Brien, and L. Diamond. 1979. Induction of differentiation of human promyelocytic leukemia cells by tumor promotors. Science (Wash. DC). 204:868-870.

14. Rovera, G., D. Ferraro, G. L. Pagliardi, J. Vartikar, S. Pessano, L. Bottera, S. Abraham, and D. Lebman. 1982. Induction of differentiation of human myeloid leukemias by phorbol esters: phenotypic changes and mode of action. Ann. NY Acad. Sci. 397:211-220.

15. Sariban, E., T. Mitchell, and D. W. Kufe. 1985. Expression of the c-fms proto-oncogene during human monocytic differentiation. Nature (Lond.). 316:64-67.

16. Sherman, M., R. Stone, R. Datta, S. Bernstein, and D. Kufe. 1990. Transcriptional and posttranscriptional regulation of c-jun expression during induction of monocytic differentiation. J. Biol. Chem. 265:3320-3323.

17. Sherr, C. J., C. W. Rettenmier, R. Sacca, M. F. Roussel, A. T. Look, and E. R. Stanley. 1985. The c-fms proto-oncogene product is related to the receptor for the mononuclear phagocyte growth factor, CSF-1. Cell. 41:665-676.

18. Terada, M., U. Nudal, E. Fibach, R. A. Rifkind, and P. A. Marks. 1978. Changes in DNA associated with induction of erythroid differentiation by dimethyl sulfoxide in murine erythroleukemic cells. Cancer Res. 38:835-840.

19. Scher, W., and C. Friend. 1978. Breakage of DNA and alterations in folded genomes by inducers of differentiation in Friend erythroleukemic cells. Cancer Res. 38:841-849.

20. Farzaneh, F., R. Zalin, D. Brill, and S. Shall. 1982. DNA strand breaks and ADP-ribosyl transferase activation during cell differentiation. Nature (Lond.). 300:362-366. 
21. Johnstone, A. P., and G. T. Williams. 1982. Role of DNA breaks and ADP-ribosyl transferase activity in eukaryotic differentiation demonstrated in human lymphocytes. Nature (Lond.). 300:368-370.

22. McMahon, G., J. L. Alsina, and S. B. Levy. 1984. Induction of $\mathrm{Ca}^{2+}, \mathrm{Mg}^{2+}-$ dependent endonuclease activity during the early stages of murine erythroleukaemic cell differentiation. Proc. Natl. Acad. Sci. USA. 81:7461-7465.

23. Krishan, A. 1975. Rapid flow cytometric analysis of mammalian cell cycle by propidium iodide staining. J. Cell Biol. 66:188-193.

24. Della-Favera, R., E. P. Gelmann, A. Martinotti, G. Franchini, T. S. Papas, R. C. Gallo, and F. Wang-Staal. 1982. Cloning and characterization of different human sequences related to the oncogene $(\mathrm{v}-\mathrm{myc})$ of avian myelocytomatosis virus (MC29). Proc. Natl. Acad. Sci. USA. 79:6497-6501.

25. Coussens, L., C. Van Beveren, D. Smith, E. Chen, R. L. Mitchell, C. M. Isacke, I. M. Verma, and A. Ullrich. 1986. Structural alteration of viral homologue of receptor proto-oncogene fms at carboxyl terminus. Nature (Lond.) 320:277-280.

26. Cleveland, D. W., M. A. Lopata, R. J. MacDonald, N. J. Cowan, W. J. Rutter, and M. W. Kirschner. 1980. Number and evolutionary conservation of an alpha- and beta-tubulin and cytoplasmic beta- and alpha-actin genes using specific cloned cDNA probes. Cell. 20:95-105.
27. Hass, R., G. Giese, G. Meyer, A. Hartmann, T. Dork, L. Kohler, K. Resch, P. Traub, and M. Goppelt-Strube. 1990. Differentiation and retrodifferentiation of U-937 cells: reversible induction and suppression of intermediate filament protein synthesis. Eur. J. Cell Biol. 51:265-271.

28. Nakamura, T., S. Kharbanda, D. Spriggs, and D. Kufe. 1990. Effects of dexamethasone on induction of monocytic differentiation in human U-937 cells by dimethyl sulfoxide. J. Cell. Physiol. 142:261-267.

29. Cohen, J. J., and R. C. Duke. 1984. Glucocorticoid activation of a calcium-dependent endonuclease in thymocyte nuclei leads to cell death. J. Immunol. $132: 38-42$.

30. Wakamiya, N., J. Horiguchi, and D. Kufe. 1987. Detection of c-fms and CSF-1 RNA by in situ hybridization. Leukemia. 1:518-520.

31. Hass, R., H.-J. Pfannkuche, S. Kharbanda, G. Meyer, A. Hartmann, K. Resch, D. Kufe, and M. Goppelt-Strube. 1991. Protein kinase C activation and proto-oncogene expression in differentiation/retrodifferentiation of human U-937 leukemia cells. Cell Growth Differ. 2:541-548.

32. Hass, R., G. Lonnemann, D. Mannel, N. Topley, A. Hartmann, L. Kohler, K. Resch, and M. Goppelt-Strube. 1991. Regulation of TNF-a, IL-1 and IL-6 synthesis in differentiating human monoblastoid leukemic U-937 cells. Leukemia Res. 5:327-339. 